\title{
Restriction Fragment Length Polymorphism (RFLP) Analysis of Progeny from an Allium fistulosum $\mathrm{X}$ A. cepa Hybrid
}

\author{
Ockyung H. Bark ${ }^{1}$ \\ Department of Horticulture, University of Wisconsin, Madison, WI 53706 \\ Michael J. Havey ${ }^{2}$ \\ U.S. Department of Agriculture, Agricultural Research Service, Department of Horticulture, University \\ of Wisconsin, Madison, WI 53706
}

\author{
Joe N. Corgan ${ }^{3}$ \\ Department of Agronomy and Horticulture, New Mexico State University, Las Cruces, NM 88003 \\ Additional index words. bulb onion, interspecific cross, Japanese bunching onion
}

\begin{abstract}
Allium fistulosum L. (bunching onion) is resistant to many of the important diseases and pests of Allium cepa L. (bulb onion). Although the first interspecific hybrids were generated more than $\mathbf{5 0}$ years ago, there is no conclusive evidence that any desirable trait in bunching onion has been successfully transferred to bulb onion by backcrossing. We identified RFLPs in the chloroplast and nuclear genomes to assess DNA transfer from bunching to bulb onion by backcrossing an interspecific hybrid to a bulb onion. Polymorphisms in the chloroplast genome established that the interspecific hybrid and three putative backcross plants had the cytoplasm of a bunching onion. All 57 random cDNA probes detected polymorphisms between the bulb and bunching onion for at least one of two restriction enzymes. The backcross progenies always possessed the bulb-onion fragments and an excess of probes detected the bunching-onion fragments. Only one plant showed an acceptable fit to the expected 1:1 backcross ratio. Significant deviations from expected segregation ratios may be the result of abnormal meiosis in the interspecific hybrid. However, these observations could also be explained by a previously proposed nuclear-cytoplasmic interaction conditioning preferential survival in the bunching-onion cytoplasm of eggs carrying bunching-onion chromosomes.
\end{abstract}

The bulb onion (Allium cepa) is the most widely grown of the cultivated alliums and originated from central Asia (Hanelt, 1990). Bunching onion (Allium fistulosum) is an important vegetable in eastern Asia, where it is as economically valuable as the bulb onion, and probably originated from northern China (Inden and Asahira, 1990). Morphological classifications have placed bulb and bunching onions into separate sections-Cepa (Mill.) Prokh. and Phyllodolon (Salisb.) Prokh., respectively (Vvedensky, 1944)_and into a single section Cepa (Hanelt, 1990). The two species differ morphologically in perianth color and shape, leaf crosssection, bulbing degree, and scape swelling (Vvedensky, 1944). A close phylogenetic relationship between bulb and bunching onions is supported by equal chromosome number $(2 \mathrm{n}=2 \mathrm{x}=16)$, similar karyotypes (Emsweller and Jones, 1935b; Fiskesjö, 1975; Vosa, 1976), amount of DNA per cell (Jones and Rees, 1968; van Raamsdonk and de Vries, 1992), cladistic analysis of RFLPs in chloroplast genome (Havey, 1991a, 1992b), and naturally occurring sterile interspecific hybrids (Allium $\times$ proliferum [Moench.] Schrad.) that reproduce asexually by vivipary (Havey, 1991b; Schubert et al., 1983).

It has long been recognized that the bunching onion is a

Received for publication 30 Sept. 1993. Accepted for publication 27 Apr. 1994. Use of trade names does not imply endorsement of the products named nor criticism of similar ones not named. We gratefully acknowledge the financial support of USDA-NRICGP 92-37300-7546. The cost of publishing this paper was defrayed in part by the payment of page charges. Under postal regulations, this paper therefore must be hereby marked advertisement solely to indicate this fact.

${ }^{1}$ Former graduate research assistant.

${ }^{2}$ Research geneticist and associate professor of horticulture. To whom reprint requests should be addressed.

${ }^{3}$ Professor of horticulture. potential source of germplasm for genetically improving the bulb onion. Bunching onion shows resistance to many of the diseases and pests of bulb onion, including pink root (Pyrenochaeta terrestris Hansen), thrips (Thrips tabaci Lindeman), smut (Urocystis cepulae Frost), and maggot (Hylemya antiqua Meig.) (Jones and Mann, 1963). Other traits potentially useful in bulb-onion improvement include low pungency, cold hardiness, and high levels of vitamins and minerals (Inden and Asahira, 1990). Interspecific hybrids have been generated to transfer disease resistance from the bunching to bulb onion (Emsweller and Jones, 1935a; Levan, 1936; Maeda, 1937), but they were sterile due to chromosome rearrangements (Emsweller and Jones, 1935b, 1938; Levan, 1941; Maeda, 1937; Peffley, 1986) and stylar incongruities (van der Valk et al., 1991). However, amphidiploids have shown increased fertility and been gown commercially from seed ('Beltsville Bunching'). McCollum (1974) observed that open pollination of $A$. ×proliferum produced progeny that were either like bunching onion or the viviparous interspecific hybrid; no cepa-like progeny were observed. He suggested that $A$. xproliferum may possess the cytoplasm of bunching onion, and eggs carrying only bunching-onion chromosomes preferentially survive. In agreement, Havey (1991b) demonstrated that $A$. xproliferum has bunching-onion cytoplasm. Peffley et al. (1985) observed that bulb-onion chromosomes preferentially pair in the triploid (two sets of bulb- and one set of bunching-onion chromosomes) shallot 'Delta Giant'. Cytological (Peffley and Mangum, 1990) and isozyme (Cryder et al., 1991) analyses provided evidence of limited recombination between, as opposed to substitution of whole, chromosomes of bulb and bunching onions. However in spite of $>50$ years of work, there is no conclusive evidence for the successful transfer of a desirable trait from bunching to bulb onion through backcrossing. 
Peffley et al. (1985) proposed to transfer germplasm from bunching to bulb onion using alien addition lines generated by backcrossing 'Delta Giant' to bulb onion. Plants carrying bunching-onion chromosomes were identified by morphological characteristics, isozyme markers, pink-root resistance, and cytological studies (Peffley et al., 1985; Peffley and Mangum, 1990). Corgan and Peffley (1986) and Cryder et al. (1991) generated interspecific crosses between bunching and bulb onions and allowed the hybrids to be open-pollinated with copious amounts of bulb-onion pollen. Isozyme patterns indicated that some $\mathrm{F}_{2}$ progeny may have occurred (Cryder et al., 1991), possibly due to the inability of pollen tubes from bulb onions to penetrate the style of interspecific hybrids (van der Valk et al., 1991).

In this study, we identified random nuclear RFLPs to assess the level of DNA polymorphism between bulb and bunching onions and objectively evaluate DNA transfer from bunching to bulb onion in first-generation backcrosses. We chose RFLPs because studies to date have relied on relatively few polymorphic isozyme loci: five by Peffley et al. (1985) and three by Cryder et al. (1991).

\section{Materials and Methods}

The plants used in this study were a subset of those described by Cryder et al. (1991). Because interspecific hybrids occur more frequently using bunching onion as the seed parent (Emsweller and Jones 1935a; van Raamsdonk et al., 1992), the bunching onion

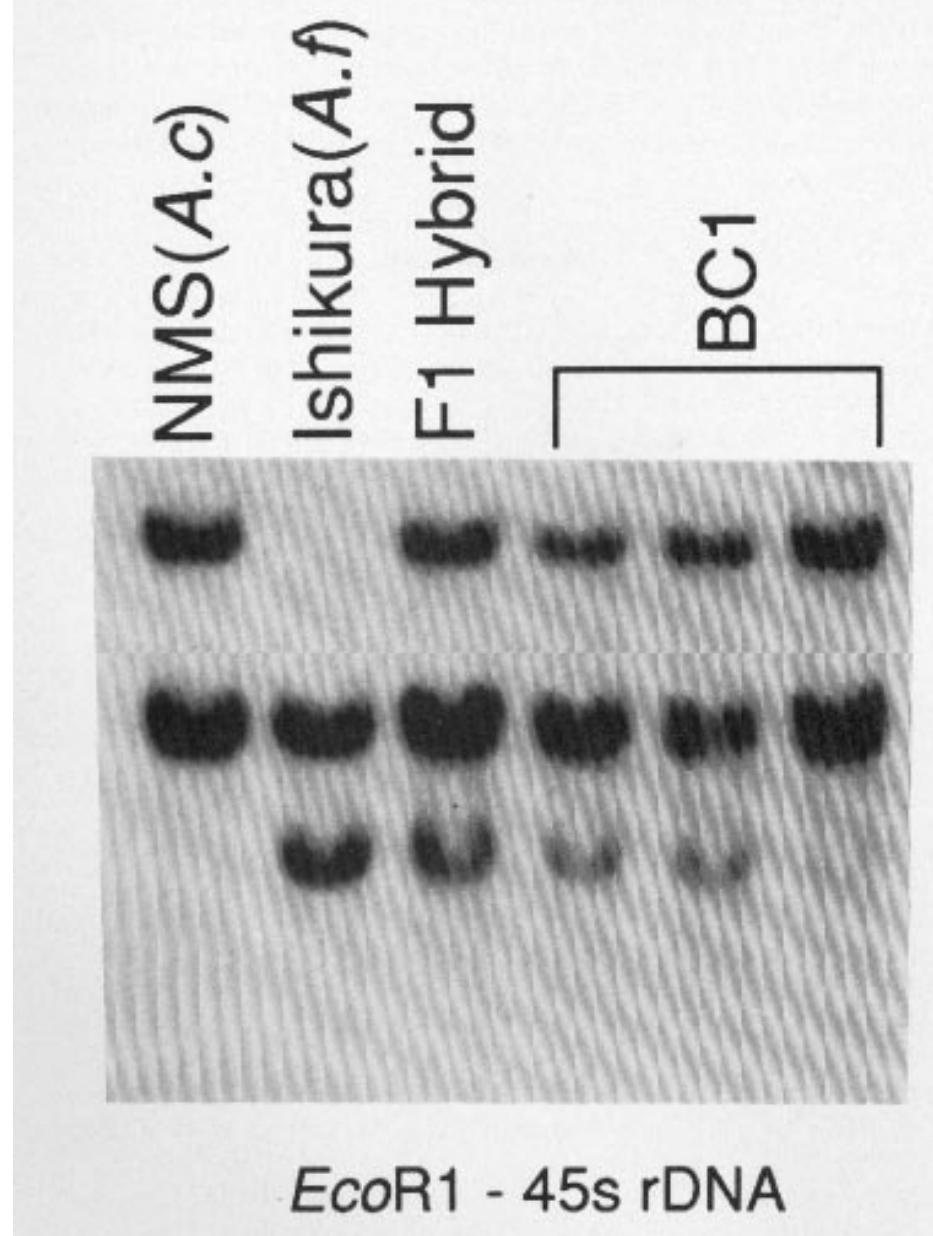

Fig. 1. Autoradiogram showing presence of polymorphic EcoRI fragments from 'NuMex Sunlite' Allium cepa and 'Ishikura' A. fistulosum in the nuclear $45 \mathrm{~s}$ ribosomal DNA of the interspecific hybrid $8273\left(\mathrm{~F}_{1}\right)$ and putative first-generation backcross plants 7163,5519 , and 2523 (lanes 4,5 , and 6 , respectively).
'Ishikura' was crossed as the maternal parent with the bulb onion 'NuMex Sunlite'. A single interspecific hybrid (8273) was divided at the stem plate and propagules were allowed to open-pollinate with copious pollen from 'NuMex Sunlite' to generate 282 progeny, of which three euploid (Ulloa, 1993) male-sterile progenies $(2523,5519$, and 7165$)$ were chosen. We selected these extremely rare euploid progenies to avoid aneuploids carrying extra chromosomes from bunching onion, although substituting whole bunching-onion chromosomes is still possible.

'NuMex Sunlite' and 'Ishikura' seeds and interspecific hybrid and progeny plants were grown in the greenhouse. Genomic DNA was extracted from lyophilized leaf tissue as previously described (Havey, 1991a). We evaluated for previously reported polymorphisms in the cpDNA (cpDNA-2 and -41) that distinguish the normal and sterile cytoplasm of bulb onion from that of bunching onion (Havey, 1992b, 1993). Two enzymes (EcoRI and HindIII) detect polymorphisms in the 45 s nuclear rDNA that distinguish bulb and bunching onions (Havey, 1992a). Electrophoresis, blotting, nick translation, hybridization of an rDNA wheat clone (Gerlach and Bedbook, 1979) or cpDNA orchid clones (Chase and Palmer, 1989), and autoradiography have been previously described (Havey 1991a, 1991b).

For random nuclear RFLPs, digestion with EcoRI or HindIII, electrophoresis, and DNA blotting, isolating and radiolabelling cDNAs, hybridizations, and autoradiography have been previously described (O.H. Bark and M.J. Havey, unpublished data). We scored the presence or absence of polymorphic fragments detected with one restriction enzyme for each probe. Goodness of fit to the expected backcross value of equal numbers of probes detecting only the bulb-onion fragment or bulb- and bunchingonion fragments was tested using the chi-squared distribution, assuming homology among the chromosomes of bunching and bulb onions and independence of probes.

\section{Results and Discussion}

Chloroplast analysis and nuclear $45 \mathrm{~s}$ ribosomal DNA. For the interspecific hybrid and three putative backcross plants, the pres-

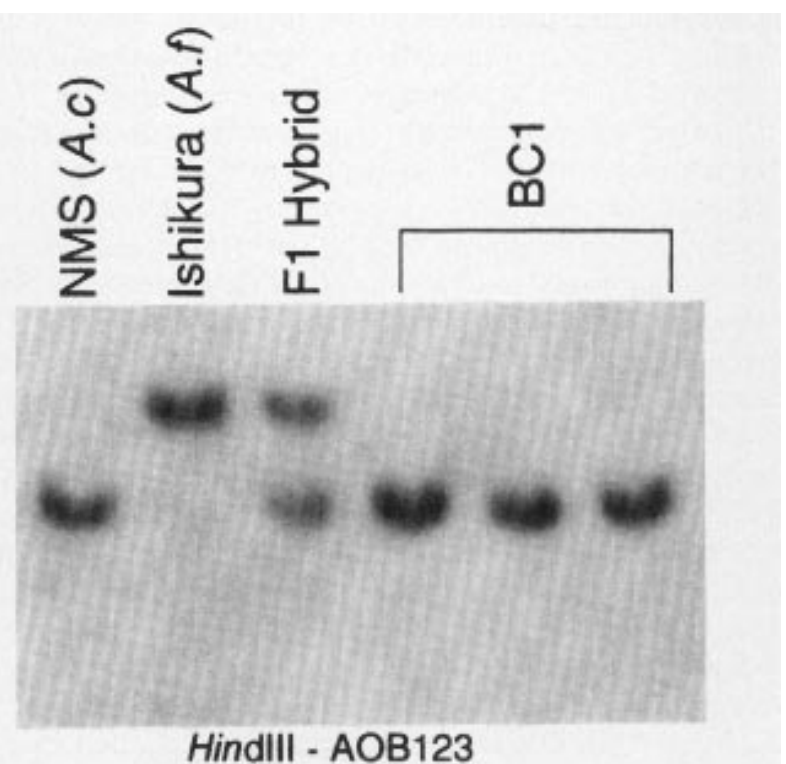

Fiq

cepa, 'Ishikura' A. fistulosum, the interspecific hybrid, and three putative firstgeneration backcross plants. DNAs were digested by HindIII and hybridized with cDNA clone AOB123. NMS = 'NuMex Sunlite'; lanes 4, 5, and 6 are putative backcross plants 7163,5519 , and 2523 , respectively. 
Table 1. Number of cDNAs detecting RFLPs between bulb and bunching onions and goodness of fit to the expected 1:1 ratio for three putative backcross plants.

\begin{tabular}{|c|c|c|c|c|}
\hline \multirow[b]{2}{*}{ Plant } & \multicolumn{2}{|c|}{ No. of probes detecting } & \multirow[b]{2}{*}{$\chi^{2}$} & \multirow[b]{2}{*}{$P$} \\
\hline & $\begin{array}{l}\text { Bulb and bunching } \\
\text { onion fragments }\end{array}$ & $\begin{array}{l}\text { Bulb onion } \\
\text { fragments }\end{array}$ & & \\
\hline 2523 & 32 & 25 & 0.860 & $0.25<P<0.50$ \\
\hline 5519 & 38 & 19 & 6.333 & $P<0.025$ \\
\hline 7163 & 43 & 14 & 14.754 & $P<0.001$ \\
\hline
\end{tabular}

ence of cpDNA-2 and the absence of cpDNA-41 established that all four plants possessed bunching-onion cytoplasm (Havey, 1992b, 1993) as expected, because cpDNA is maternally inherited (Corriveau and Coleman, 1988; Tatabe, 1961, 1968). The interspecific hybrid and two of the three progenies (5519 and 7163) clearly showed bulb- and bunching-onion rDNA fragments (Fig. 1). The third plant (2523) showed a light band equal in size to the unique bunching-onion fragment. Bunching onion has a single prominent nucleolus organizer region (NOR) (Vosa, 1976). Pairing bulb- and bunching-onion chromosomes that carry the NOR and crossing over within this region could transfer a subset of the unique bunching-onion rDNA fragment to the progeny. Alternatively, the few bunching-onion rDNA fragments in 2523 may have resulted from NOR jumping, a phenomenon described by Schubert and Wobus (1985) in naturally occurring interspecific hybrids between bulb and bunching onions.

Nuclear RFLP analysis using random cDNAs. All 57 cDNA clones detected polymorphisms between bulb and bunching onion for at least one of the two restriction enzymes. Although both species have been classified into the same section (Hanelt, 1990), they have acquired a significant level of DNA polymorphism. Bulb- and bunching-onion chromosomes have undergone differentiation, as evidenced by heteromorphic bivalents due to changes in chromosome length (Jones, 1983) and at least one inversion and translocation (Emsweller and Jones, 1935b; Maeda, 1937; Peffley, 1986). Based on these cytological studies and the fact that RFLPs are consistently observed with more than one restriction enzyme, we infer that the high level of polymorphism between bulb and bunching onions is primarily due to structural rearrangements rather than point mutations at restriction-enzyme sites.

As expected, polymorphic fragments from both species were always observed in the interspecific hybrid. The three putative backcross progenies always possessed the bulb-, but not the bunching-onion fragment (Fig. 2). We could not determine if polymorphic bands were allelic, nor if the presence of two polymorphic bands were the result of recombination among chromosomes of the two species or from substitutions of whole chromosomes. Homology and recombination among bunching- and bulbonion chromosomes have been inferred by observing bivalent pairing between the satellited chromosomes (Emsweller and Jones, 1945; Levan, 1941; Maeda, 1937; Peffley, 1986) and backcross progenies exhibiting recombinant genotypes at isozyme loci (Cryder et al., 1991). Under conditions of normal meiosis and independence of probes, an equal proportion of probes should detect only the bulb-onion fragment or bulb- and bunching-onion fragments. Only 2523 showed an acceptable fit $(P>0.25)$ to the expected ratio of 1:1 (Table 1). The number of probes detecting bunching-onion fragments in 5519 and 7163 was too great to fit the backcross ratio (Table 1). Because no probe revealed only bunching-onion fragments, none of the putative backcross progenies fit the 1:2:1 ratio expected from self-pollination of the interspecific hybrid $(P<$ 0.001). Cryder et al. (1991) estimated that $5 \%$ to $10 \%$ of putative backcross progenies resulted from selfing or intercrossing among interspecific hybrids. Although the stylar incongruities reported by van der Valk et al. (1991) could increase the frequency of self pollinations, the significant deviations from equal proportions of bulb- and bunching-onion fragments in our progenies and the distorted segregation ratios for isozymes reported by Cryder et al. (1991) could have resulted from abnormal meiosis in the interspecific hybrid. Another consistentexplanation was offered by McCollum (1974), who postulated the existence of a nuclear-cytoplasmic interaction allowing preferential survival in the bunching-onion cytoplasm of eggs carrying bunching-onion chromosomes.

Our results further illustrate the difficulty of sexual gene transfer from bunching to bulb onion by backcrossing. Thousands of pollinations produced 282 putative backcross progenies (Cryder et al., 1991), from which we chose three euploid plants. It is likely that the progenies are true backcrosses to bulb onion, as evidenced by the bulb-onion fragments always present. However, abnormal meiosis in the interspecific hybrid and preferential survival of eggs carrying bunching-onion chromosomes would compromise genetic studies. The degree of cytological abnormalities and fertility of interspecific crosses may be cultivar dependent (Emsweller and Jones, 1945; van der Meer and van Benekom, 1978), a result suggesting that using more compatible cultivars may enhance the success of sexual gene transfer (Cryder et al., 1989). However, it may be advantageous to do large numbers of interspecific crosses with a normal-fertile-cytoplasmic bulb onion as the seed parent to avoid the sterility associated with alien cytoplasms (Havey, 1993). If more-compatible cultivars existed, the plethora of nuclear RFLPs between these two species would be useful to establish the degree of recombination among chromosomes to estimate the likelihood of beneficial gene transfer from bunching to bulb onion through backcrossing.

\section{Literature Cited}

Chase, M. and J. Palmer. 1989. Chloroplast DNA systematics of lilioid monocots, feasibility, resources, and an example from the Orchidaceae. Amer. J. Bot. 76:1920-730.

Corgan, J. and E. Peffley. 1986. Notice of release of Allium genetic materials (asexual propagules). New Mexico Agr. Expt. Sta., Las Cruces.

Corriveau, J. and A. Coleman. 1988. Rapid screening method to detect biparental inheritance of plastid DNA and results from over 200 angiosperm species. Amer. J. Bot. 75:1443-1458.

Cryder, C., J. Corgan, N. Urquhart, and D. Clason. 1991. Isozyme analysis of progeny derived from (Allium fistulosum $\mathrm{x}$ Allium cepa) $\times$ Allium cepa. Theoretical Applied Genet. 82:337-345.

Cryder, C., J. Corgan, N. Urquhart, and D. Clason. 1989. A study of progeny from the interspecific backcross (A. fistulosum $\times$ A. cepa) $\times$ A. сера. Proc. Natl. Onion Res. Conf., Boise, Idaho. p. 79-84.

Emsweller, S. and H. Jones. 1935a. An interspecific hybrid in Allium. Hilgardia 9:265-273.

Emsweller, S. and H. Jones. 1935b. Meiosis in Allium fistulosum, Allium cepa, and their hybrid. Hilgardia 9:277-294.

Emsweller, S. and H. Jones. 1938. Crossing over, fragmentation, and formation of new chromosomes in an Allium species hybrid. Bot. Gaz. 99:729-772.

Emsweller, S. and H. Jones. 1945. Further studies on the chiasmata of the A. cepa $\times$ A. fistulosum hybrid and its derivatives. Amer. J. Bot. 32:370379.

Fiskesjö, G. 1975. Chromosomal relationships between the species of Allium as revealed by C-banding. Hereditas 81:23-32.

Gerlach, W. and J. Bedbrook. 1979. Cloning and characterization of ribosomal RNA genes from wheat and barley. Nucleic Acid Res. 7:1869-1885.

Hanelt, P. 1990. Taxonomy, evolution, and history, p. 1-26. In: J. 
Brewster and H. Rabinowitch (eds.). Onions and allied crops. vol. 1. CRC Press, Boca Raton, Fla.

Havey, M. 1991a. Phylogenetic relationships among cultivated Allium species from restriction enzyme analysis of the chloroplast genome. Theoretical Applied Genet. 81:752-757.

Havey, M. 1991b. Molecular characterization of the interspecific origin of the viviparous onion. J. Hered. 82(6):501-503.

Havey, M. 1992a. Restriction enzyme analysis of the nuclear 45s ribosomal DNA of six cultivated Alliums (Alliaceae). Plant Syst. Evol. 181:45-55.

Havey, M. 1992b. Restriction enzyme analysis of the chloroplast and nuclear 45s ribosomal DNA of Allium sections Cepa and Phyllodolon. Plant Syst. Evol. 183:17-31.

Havey, M. 1993. A putative donor of S-cytoplasm and its distribution among open-pollinated populations of onion. Theoretical Applied Genet. 86:128-134.

Inden, H. and T. Asahira. 1990. Japanese bunching onion (Alliumfistulosum L.), p. 159-178. In: J. Brewster and H. Rabinowitch (eds.). Onions and allied crops. vol. 3. CRC Press, Boca Raton, Fla.

Jones, H. and L. Mann. 1963. Onions and their allies. Interscience Publishers, New York.

Jones, R. 1983. Cytogenetic evolution in the genus Allium, p. 516-554. In: M. Swaninathan, P. Gupta, and V. Sinha (eds.). Cytogenetics of crop plants. MacMillan, New York.

Jones, R. and H. Rees. 1968. Nuclear DNA variation in Allium. Heredity 23:591-605.

Levan, A. 1936. Die Zytologie von Allium cepa X A. fistulosum. Hereditas 21:195-214.

Levan, A. 1941. The cytology of the species hybrid Allium cepa $\mathrm{x}$ fistulosum and its polyploid derivatives. Heredity 27:253-272.

Maeda, T. 1937. Chiasma studies in Allium fistulosum, Allium cepa, and their $\mathrm{F}_{1}, \mathrm{~F}_{2}$ and backcross hybrids. Jpn. J. Genet. 13:146-159.

McCollum, G. 1974. Hybrid origin of top onion, Allium cepa var. viviparum. Z. Pflanzenzücht. 71:222-232.

Peffley, E. 1986. Evidence for chromosomal differentiation of Allium fistulosum and A. cepa. J. Amer. Soc. Hort. Sci. 111:126-129.

Peffley, E., J. Corgan, K. Horak, and S. Tanksley. 1985. Electrophoretic analysis of Allium alien addition lines. Theoretical Applied Genet. 71:176-184.

Peffley, E. and P. Mangum. 1990. Introgression of Allium fistulosum L. into Allium cepa L.: Cytogenetic evidence. Theoretical Applied Genet. 79:113-118.

Schubert, I., H. Ohle, and P. Hanelt. 1983. Phylogenetic conclusions from Giemsa banding and NOR staining in top onions (Liliaceae). Plant Syst. Evol. 143:245-256.

Schubert, I. and U. Wobus. 1985. In situ hybridization confirms jumping of nucleolus organizing regions in Allium. Chromosoma 92:143-148.

Tatabe, T. 1961. Genetic studies on the leaf variegation of Allium fistulosum L. Jpn. J. Genet. 36:151-156.

Tatabe, T. 1968. Genetic studies on the leaf variegation of Allium cepa $\mathrm{L}$. J. Jpn. Soc. Hort. Sci. 37:345-348.

Ulloa, M. 1993. A cytogenetic, isozyme, and morphological study on interspecific $\mathrm{F}_{1}, \mathrm{~F}_{2}$, and backcross progenies from Allium fistulosum by A. cepa crosses. PhD diss. New Mexico State Univ., Las Cruces.

van der Meer, Q. and J. van Benekom. 1978. Improving the onion crop ( $A$. cepa $\mathrm{L}$.) by transfer of characters from A. fistulosum L. Biul. Warzywniczy 22:87-91.

van der Valk, P., S. de Vries, J. Evedink, F. Verstappen, J. de Vries. 1991. Pre- and post-fertilization barriers to backcrossing the interspecific hybrid between Allium fistulosum L. and A. cepa L. with A. cepa. Euphytica 53:201-209.

van Raamsdonk, L. and T. de Vries. 1992. Biosystematic studies in Allium L. section Cepa. Bot. J. Linn. Soc. 109:131-143.

van Raamsdonk, L., W. Wietsma, and J. de Vries. 1992. Crossing experiments in Allium L. section Cepa. Bot. J. Linn. Soc. 109:293-303.

Vosa, C. 1976. Heterochromatic patterns in allium. I. The relationship between the species of the cepa group and its allies. Heredity 36:383392.

Vvedensky, A. 1944. The genus Allium in the USSR. Herbertia 11:65218. 